\title{
Insulin and insulin receptor gene polymorphisms and susceptibility to nonalcoholic fatty liver disease
}

\author{
Hossein NOBAKHT ${ }^{1}$, Touraj MAHMOUDI ${ }^{2}$, Mohammad SABZIKARIAN ${ }^{3}$, Seidamir Pasha TABAEIAN ${ }^{3}$, \\ Gholamreza REZAMAND ${ }^{3}$, Asadollah ASADI ${ }^{4}$, Hamid FARAHANI ${ }^{5}$, Reza DABIRI', \\ Fariborz MANSOUR-GHANAEI ${ }^{6}$, Iradj MALEKI ${ }^{7}$ and Mohammad Reza ZALI ${ }^{2}$
}

Received: 18 February 2020 Accepted: 23 March 2020

ABSTRACT - Background - Nonalcoholic fatty liver disease (NAFLD) is an increasing global health concern defined by excessive hepatic fat content in the absence of excessive alcohol consumption. Objective - Given the pivotal role of insulin resistance in NAFLD, we hypothesized that insulin (INS) and insulin receptor (INSR) gene polymorphisms may be associated with NAFLD risk. Methods - A total of 312 subjects, including 153 cases with biopsy-proven NAFLD and 159 controls were enrolled in this case-control study. Four polymorphisms in INS (rs3842752, rs689) and INSR (rs1052371, rs1799817) genes were genotyped using PCR-RFLP method. Results - The cases with NAFLD were older and had higher BMI, systolic blood pressure, diastolic blood pressure, as well as higher serum levels of aspartate aminotransferase, alanine aminotransferase, and gamma glutamyl transferase than the controls $(P<0.001)$. The "TT" genotype of INSR rs1799817 compared with "CC" genotype occurred more frequently in the controls than the cases with NAFLD and the difference remained significant after adjustment for confounding factors $(P=0.018$; OR $=0.10,95 \% \mathrm{CI}=0.02-0.76)$. However, no significant difference was found for INS rs3842752, INS rs689, and INSR rs1052371 gene polymorphisms between the cases with NAFLD and the controls either before or after adjustment for the confounders. Conclusion - These findings corroborate the hypothesis that genetic polymorphisms related to insulin resistance play a role in NAFLD susceptibility. Specifically, the INSR rs1799817 "TT" genotype had a protective effect for NAFLD. However, our results remain to be validated in other studies.

HEADINGS - Non-alcoholic fatty liver disease. Insulin resistance. Insulin receptor. Genetic polymorphism.

\section{INTRODUCTION}

Nonalcoholic fatty liver disease (NAFLD) - the most prevalent chronic liver disorder - is an increasing and serious worldwide health concern. It is considered the hepatic expression of metabolic syndrome and defined by excessive hepatic fat content in the absence of excessive alcohol consumption. NAFLD encompasses a broad range of histological changes varying from simple steatosis to non-alcoholic steatohepatitis (NASH) with potential for progression to cirrhosis and hepatocellular carcinoma. Owing to the very high global prevalence of NAFLD, twenty-five percent, it is of paramount importance to understand its pathogenesis ${ }^{(1)}$.

Notwithstanding efforts, the etiology of NAFLD and the reasons for its progression to NASH has not been fully comprehended yet. Nevertheless, it is well established that NAFLD is strongly connected with metabolic disorders such as abnormal glucose tolerance ${ }^{(2)}$, insulin resistance (IR) $)^{(3,4)}$, type 2 diabetes (T2D) $)^{(5)}$, and obesity $^{(6)}$. So, IR is one of the underlying causes of NAFLD. The severity of histological progression of NAFLD is closely related to insulin sensitivity independent of body mass index (BMI) ${ }^{(7)}$, as well as NASH patients compared with the patients with simple fatty liver have more severe $\operatorname{IR}^{(8)}$. Additionally, NAFLD patients with IR in comparison to those without IR show much higher rates of elevated liver enzymes of aspartate aminotransferase and alanine aminotransferase $^{(9)}$. Furthermore, NAFLD patients have a higher circulating level of insulin than controls ${ }^{(10)}$. And finally, significant associations between insulin (INS) and insulin receptor (INSR) gene polymorphisms and circulating insulin levels ${ }^{(11,12)}, \operatorname{IR}^{(13,14)}$, $\mathrm{BMI}^{(15)}$ and risk of $\mathrm{T} 2 \mathrm{D}^{(16,17)}$ have been reported.

Therefore, these observations led us to investigate whether insulin resistance-related genes (INS and INSR) were associated with NAFLD risk in Iranian population.

Declared conflict of interest of all authors: none

Disclosure of funding: This work was supported by grants from Iran National Science Foundation (INSF) [grant number 90005942] and Gastroenterology and Liver Diseases Research Center, Shahid Beheshti University of Medical Sciences [grant number 1422].

Researche performed at: Research Institute for Gastroenterology and Liver Diseases, Shahid Beheshti University of Medical Sciences.

${ }^{1}$ Semnan University of Medical Sciences, Internal Medicine Department, Semnan, Iran. ${ }^{2}$ Shahid Beheshti University of Medical Sciences, Research Institute for Gastroenterology and Liver Diseases, Gastroenterology and Liver Diseases Research Center, Tehran, Iran. ${ }^{3}$ Iran University of Medical Sciences, Colorectal Research Center, Tehran, Iran. ${ }^{4}$ University of Mohaghegh Ardabili, Faculty of Science, Department of Biology, Ardabil, Iran. ${ }^{5}$ Qom University of Medical Sciences, School of Medicine, Department of Physiology and Pharmacology, Qom, Iran. ${ }^{6}$ Guilan University of Medical Sciences, Gastrointestinal and Liver Diseases Research Center (GLDRC), Division of Gastroenterology and Hepatology, Rasht, Iran. ${ }^{7}$ Mazandaran University of Medical Sciences, Gut and Liver Research Center, Sari, Iran.

Corresponding author: Touraj Mahmoudi. E-mail: mahmouditouraj@gmail.com 


\section{METHODS}

\section{Participants}

The study population consisted of 159 controls (age range, 33-82 years) and 153 cases with biopsy-proven NAFLD (age range, 32-88 years). This hospital based case-control study was a multicenter research and the centers are as follows: (1) Research Institute for Gastroenterology and Liver Diseases, Shahid Beheshti University of Medical Sciences (2) Gastrointestinal and Liver Diseases Research Center, Guilan University of Medical Sciences (3) Internal Medicine Department, Semnan University of Medical Sciences (4) Colorectal Research Center, Iran University of Medical Sciences (5) Faculty of Science, University of Mohaghegh Ardabili (6) School of Medicine, Qom University of Medical Sciences (7) Gut and Liver Research Center, Mazandaran University of Medical Sciences. All the participants were Iranian and genetically unrelated. They were informed about the aims of the study and their demographic, anthropometric, and clinical information was collected by self-administered questionnaires and before diagnosis of NAFLD. NAFLD diagnosis was established in accordance with the following criteria: (1) ultrasonographic evidence of fatty liver and high serum levels of liver enzymes (ALT, AST, GGT) (2) alcohol consumption $<20 \mathrm{~g} /$ day in men and $<10 \mathrm{~g} /$ day in women (3) excluding patients with other causes of liver disease including viral hepatitis, Wilson's disease, alpha-1 antitrypsin deficiency, and use of drugs known to induce steatosis (4) histologic confirmation of NAFLD by an experienced pathologist who was unaware of the patients' clinical and biochemical data and scored biopsies using the Brunt's criteria. Steatosis and necroinflammation were graded from 0 to 3 and fibrosis was staged from 0 to $4^{(18)}$. The controls had no liver steatosis (examined by abdominal ultrasonography), neither elevated liver enzymes and viral hepatitis infection (examined by blood test). None of them were alcoholics, drank regularly nor were on regular medications. The controls subjects were recruited from the institute staff and medical students. The Ethical Committee of the Institute reviewed and approved this study which was conducted according to the principles of the Helsinki Declaration. BMI of each subject was calculated by the standard formula: weight $\mathrm{kg} /$ height squared $\left(\mathrm{m}^{2}\right)$.

\section{Genotype analysis}

Five milliliters of peripheral blood samples from each of the 312 subjects were collected in tubes containing ethylene diaminetetraacetic acid (EDTA) as an anticoagulant and store at $4^{\circ} \mathrm{C}$. In this study, genomic DNA was purified from peripheral blood leucocytes using standard methods. Using PCR-RFLP method all the four studied polymorphisms (INS rs3842752, INS rs689, INSR rs1052371, and INSR rs1799817) were genotyped. Our criteria for selecting these SNPs were their position in the gene (exon, promoter or regulatory regions), use in previous genetic studies, and relatively high minor allele frequency (MAF). Moreover, laboratory personnel who carried out the genotyping were blinded to case or control status. TABLE 1 indicates the details of the PCR and RFLP conditions. The PCR products were digested with the appropriate restriction enzymes (Fermentas, Leon-Rot, Germany) and the digested products were run on $2.5 \%$ to $3.5 \%$ agarose gels and then stained with ethidium bromide for visualization under UV light. Genotyping of the subjects were denoted on the basis of the digestion patterns and the presence or absence of the respective restriction enzymes sites. To check for genotyping error rate, we repeated the genotyping analysis of around $20 \%$ of the samples that were selected randomly.

\section{Statistical methods}

Chi-square $\left(\chi^{2}\right)$ test or t-test were used to compare differences in demographic, anthropometric or clinical parameters between the cases with NAFLD and controls. We also calculated differences in the allele frequencies of polymorphisms between the different groups using $\chi^{2}$ test. To examine the distribution of the genotype frequencies logistic regression analysis was used. Logistic regression was also computed for adjusting confounding factors such as age and BMI. For all the alleles and genotypes, the odds ratios (OR) which present the measure of associations were given with the respective $95 \%$ confidence intervals $(95 \%$ CI). Statistical analyses were performed with SPSS software for Windows, version 25.0 (SPSS Inc. Chicago, IL, USA). In all statistical tests, a $P<0.05$ was considered to indicate a statistically significant difference.

TABLE 1. Insulin (INS) and insulin receptor (INSR) gene SNPs.

\begin{tabular}{|c|c|c|c|c|c|c|}
\hline Gene & $\begin{array}{c}\text { SNP ID } \\
\text { (base change) }\end{array}$ & Primer sequence (forward and reverse) & $\begin{array}{l}\text { Annealing } \\
\text { temperature }\end{array}$ & $\begin{array}{l}\text { PCR product } \\
\text { size (bp) }\end{array}$ & $\begin{array}{l}\text { Restriction } \\
\text { enzyme }\end{array}$ & $\begin{array}{l}\text { RFLP products } \\
\text { size (bp) }\end{array}$ \\
\hline \multirow[t]{2}{*}{ INS } & rs3842752(C/T) & 5'-TGTGGAACAATGCTGTACC-3' & $57^{\circ} \mathrm{C}$ & 410 & PstI & C: 410 \\
\hline & & 5'-GCTACTGAACAAGAAGTCAC-3' & & & & $\mathrm{T}: 336+74$ \\
\hline \multirow[t]{2}{*}{ INS } & rs689 (T/A) & 5'-TCCAGGACAGGCTGCATCAG-3' & $58^{\circ} \mathrm{C}$ & 441 & Alw26I & A: 441 \\
\hline & & 5'-AGCAATGGGCGGTTGGCTCA-3' & & & & $\mathrm{T}: 230+211$ \\
\hline \multirow[t]{2}{*}{ INSR } & rs1052371 (T/C) & 5'-CTAGTCAAGGTCCAGAACC-3’' & $57^{\circ} \mathrm{C}$ & 224 & LweI & $\mathrm{T}: 224$ \\
\hline & & 5'-AGGCACACAAAGGGACGAG-3' & & & & $C: 154+70$ \\
\hline \multirow[t]{2}{*}{ INSR } & rs1799817 (T/C) & 5'-CCAAGGATGCTGTGTAGATAAG-3' & $60{ }^{\circ} \mathrm{C}$ & 317 & Eco72I & $\mathrm{T}: 317$ \\
\hline & & 5'-TCAGGAAAGCCAGCCCATGTC-3' & & & & $C: 274+43$ \\
\hline
\end{tabular}




\section{RESULTS}

TABLE 2 presents demographic, anthropometric, clinical, and biochemical characteristics of the cases with NAFLD and the controls. The cases were older $(P<0.001)$, more likely to be overweight/ obese $(P<0.001)$, males $(P<0.001)$, and smokers $(P=0.015)$ than the controls. Moreover, systolic blood pressure (SBP), diastolic blood pressure (DBP), as well as circulating levels of aspartate aminotransferase (AST), alanine aminotransferase (ALT), and gamma glutamyl transferase (GGT) were higher in the cases with NAFLD compared with the controls $(P<0.001)$.

The distribution of genotypes and alleles of INS rs3842752, INS rs689, INSR rs1052371, and INSR rs1799817 gene polymorphisms in cases with NAFLD and controls are provided in TABLE 3. The carriers of the INSR rs1799817 "TT" genotype compared with the carriers of the "CC" genotype were associated with a decreased risk for NAFLD, and the difference remained significant even after adjustment for confounding factors including age, BMI, sex, smoking status, SBP, and DBP $(P=0.018$; OR $=0.10,95 \% \mathrm{CI}$

TABLE 2. Selected variables of the study participants by cases and controls*.

\begin{tabular}{|c|c|c|c|}
\hline Variables & $\begin{array}{c}\text { Controls } \\
(n=159)\end{array}$ & $\begin{array}{c}\text { Cases with } \\
\text { nonalcoholic fatty } \\
\text { liver disease }(n=153)\end{array}$ & $P$-value \\
\hline Age (years) & $29.5(7.4)$ & $38.3(9.2)$ & $<0.001$ \\
\hline $\mathrm{BMI}\left(\mathrm{kg} / \mathrm{m}^{2}\right)$ & $23.7(3.1)$ & $29.2(5.3)$ & $<0.001$ \\
\hline \multicolumn{4}{|l|}{ Gender } \\
\hline Men & $83(52.2)$ & $112(73.2)$ & \\
\hline Women & $76(47.8)$ & $41(26.8)$ & $<0.001$ \\
\hline \multicolumn{4}{|l|}{ Smoking status } \\
\hline Never smoker & $145(91.2)$ & $114(74.5)$ & \\
\hline Former smoker & $9(5.7)$ & $20(13.1)$ & \\
\hline Current smoker & $5(3.1)$ & $19(12.4)$ & 0.015 \\
\hline $\mathrm{SBP}(\mathrm{mmHg})$ & $114.3(13.5)$ & $123.7(15.2)$ & $<0.001$ \\
\hline $\mathrm{DBP}(\mathrm{mmHg})$ & $69.8(8.4)$ & $74.7(9.6)$ & $<0.001$ \\
\hline AST (IU/L) & $19.8(7.4)$ & $39.1(17.9)$ & $<0.001$ \\
\hline ALT (IU/L) & $19.6(10.5)$ & $71.9(40.6)$ & $<0.001$ \\
\hline GGT (IU/L) & $18.7(8.8)$ & $58.0(31.1)$ & $<0.001$ \\
\hline \multicolumn{4}{|l|}{ Steatosis } \\
\hline Grade 0 & & - & \\
\hline Grade 1 & & $40(26.1)$ & \\
\hline Grade 2 & & $82(53.6)$ & \\
\hline Grade 3 & & $31(20.3)$ & \\
\hline \multicolumn{4}{|l|}{ Necroinflammation } \\
\hline Grade 0 & & $47(30.7)$ & \\
\hline Grade 1 & & $59(38.6)$ & \\
\hline Grade 2 & & $45(29.4)$ & \\
\hline Grade 3 & & $2(1.3)$ & \\
\hline \multicolumn{4}{|l|}{ Fibrosis } \\
\hline Stage 0 & & $90(58.8)$ & \\
\hline Stage 1 & & $56(36.6)$ & \\
\hline Stage 2 & & $7(4.6)$ & \\
\hline Stage 3 & & - & \\
\hline Stage 4 & & - & \\
\hline
\end{tabular}

$=0.02-0.76$ ). In other words, the INSR rs1799817 "TT" genotype had a $90 \%$ decreased risk for NAFLD. Nevertheless, as shown in TABLE 3, no statistically significant difference in genotype or allele frequencies between the two groups of cases and controls was found for INS rs3842752, INS rs689, and INSR rs1052371 gene polymorphisms either before or after adjustment for confounding factors including age, BMI, sex, smoking status, SBP, and DBP.

TABLE 3. Distribution of insulin (INS) and insulin receptor (INSR) gene polymorphisms in cases with nonalcoholic fatty liver disease (NAFLD) and in controls".

\begin{tabular}{lccc}
\hline Gene (variant) & $\begin{array}{c}\text { Controls } \\
(\mathrm{n}=159)\end{array}$ & $\begin{array}{c}\text { Cases } \\
(\mathrm{n}=153)\end{array}$ & $\begin{array}{c}\text { OR }(95 \% \mathrm{CI}) \\
\boldsymbol{P} \text {-value }\end{array}$ \\
\hline
\end{tabular}

INS (rs3842752)

Genotype-wise comparison

$\begin{array}{lccc}\text { CC } & 124(78.0) & 107(69.9) & 1.0 \text { (reference) } \\ \text { CT } & 21(13.2) & 34(22.2) & 1.84(0.41-8.33) 0.427 \\ \text { TT } & 14(8.8) & 12(7.9) & 0.35(0.04-3.22) 0.353 \\ \text { CT and TT } & 35(22.0) & 46(30.1) & 1.07(0.31-3.72) 0.910 \\ \text { TT versus others } & 14(8.8) & 12(7.9) & 0.32(0.04-2.94) 0.315\end{array}$

Allele-wise comparison

\begin{tabular}{|c|c|c|}
\hline $\mathrm{C}$ & 269 (84.6) & $248(81.1)$ \\
\hline$\pi$ & $49(15.4)$ & 58 (18.9) \\
\hline
\end{tabular}

INS (rs689)

Genotype-wise comparison

$\begin{array}{lccc}\text { AA } & 113(71.1) & 104(68.0) & 1.0 \text { (reference) } \\ \text { AT } & 37(23.2) & 44(28.7) & 1.85(0.61-7.22) 0.793 \\ \text { TT } & 9(5.7) & 5(3.3) & 0.68(0.32-7.02) 0.513 \\ \text { AT and TT } & 46(28.9) & 49(32.0) & 1.75(0.88-5.43) 0.311 \\ \text { TT versus others } & 9(5.7) & 5(3.3) & 0.59(0.06--3.76) 0.422\end{array}$

Allele-wise comparison

\begin{tabular}{|c|c|c|c|}
\hline A & $263(82.7)$ & $252(82.4)$ & 1.0 (reference) \\
\hline $\mathrm{T}$ & $55(17.3)$ & $54(17.6)$ & $1.08(0.91-1.88) 0.877$ \\
\hline
\end{tabular}

INSR (rs1052371)

Genotype-wise comparison

\begin{tabular}{|c|c|c|c|}
\hline TT & $110(69.2)$ & $94(61.4)$ & ference) \\
\hline $\mathrm{TC}$ & $41(25.8)$ & $53(34.6)$ & $0.42(0.05-3.84) 0.443$ \\
\hline $\mathrm{C}$ & $8(5.0)$ & $6(4.0)$ & $1.02(0.30-3.43) 0.979$ \\
\hline $\mathrm{C}$ & $49(30.8)$ & $59(38.6)$ & $0.86(0.28-2.68) 0.797$ \\
\hline C & $8(5.0)$ & $6(4.0)$ & $0.42(0.05-3.66) 0.43$ \\
\hline
\end{tabular}

Allele-wise comparison

$\begin{array}{cccc}\mathrm{T} & 261(82.1) & 241(78.8) & 1.0 \text { (reference) } \\ \mathrm{C} & 57(17.9) & 65(21.2) & 1.23(0.69-2.18) 0.484\end{array}$

INSR (rs1799817)

Genotype-wise comparison

\begin{tabular}{|c|c|c|c|}
\hline $\mathrm{CC}$ & $107(67.3)$ & $105(68.6)$ & erence) \\
\hline $\mathrm{CT}$ & $28(17.6)$ & $35(22.9)$ & 52) 0.203 \\
\hline $\mathrm{T}$ & $24(15.1)$ & $13(8.5)$ & $0.10(0.02-$ \\
\hline $\mathrm{T}$ & $52(32.7)$ & $48(31.4)$ & $0.84(0.35-1.83) 0.417$ \\
\hline$\Gamma \mathrm{T} v$ & $24(15.1)$ & $13(8.5)$ & $0.36(0.13-1.29) 0.16$ \\
\hline
\end{tabular}

Allele-wise comparison

\begin{tabular}{|c|c|c|}
\hline C & $242(76.1) \quad 245(80.1)$ & 1.0 (reference) \\
\hline $\mathrm{T}$ & $76(23.9) \quad 61(19.9)$ & $0.89(0.64-1.41) 0.520$ \\
\hline
\end{tabular}




\section{DISCUSSION}

This case-control study was conducted to explore whether INS and INSR gene polymorphisms were associated with NAFLD risk. The "TT" genotype of INSR rs1799817 compared with "CC" genotype occurred more frequently in controls than cases with NAFLD and consequently "TT" genotype had a protective effect for NAFLD. Furthermore, this difference remained significant after adjustment for confounding factors including age, BMI, sex, smoking status, SBP, and DBP. Nevertheless, no significant difference was found for INSR rs1052371, INS rs3842752, and INS rs689 gene polymorphisms in either genotype or allele frequencies between the cases with NAFLD and the controls.

The underlying mechanisms of the pathogenesis of NAFLD still remain unclear, however, IR plays a pivotal role in the development and progression of NAFLD. IR expedites the release of free fatty acid from adipose tissue and its influx into $\operatorname{liver}^{(3,4,19)}$. Previous epidemiological reports have also revealed that HOMA-IR index is an independent predictor of the severity of liver fibrosis and the risk of disease progression increases in the patients with IR. It appears that insulin secretion increases in NAFLD patients to compensate for reduced insulin sensitivity to maintain glucose homeostasis in these patients ${ }^{(20,21)}$. NAFLD has a significant genetic basis and its association with gene variants has been investigated over the past two decades. As insulin signaling pathway genes play crucial roles in glucose homeostasis, it is not surprising that they are potential candidate genes for metabolic disorders such as NAFLD and their dysregulation may lead to NAFLD ${ }^{(22)}$.

The INSR gene, containing 22 exons, is located on short arm of chromosome 19 and encodes INSR. INSR mediates the pleiotropic biological actions of insulin through its potential ability for modulation of the expression of target genes. Therefore, any defects in INSR gene might impair the biological response to insulin and lead to IR. Previous studies demonstrated that liver-specific INSR knockout mice suffer from serious insulin resistance and glucose intolerance ${ }^{(23)}$. And INSR gene mutations were detected in many patients with insulin resistance ${ }^{(24)}$. Furthermore, INSR gene polymorphisms are associated with plasma insulin concentration ${ }^{(12)}, \mathrm{IR}^{(13,14)}, \mathrm{BMI}^{(15)}$ and risk of $\mathrm{T}^{2} \mathrm{D}^{(16)}$. In the present study, the associations between INSR rs1052371 and INSR rs1799817 polymorphisms and NAFLD susceptibility were investigated. No significant difference was observed for rs 1052371 variant - located in the 3' untranslated region (3'UTR) of the INSR gene - between the cases with NAFLD and the controls. The 3'UTR region plays a key role in regulating gene expression and its mutations have been linked to some diseases including different cancers ${ }^{(25)}$. Furthermore, the SNPs in UTRs of the INSR gene are associated with insulin resistance ${ }^{(26)}$. Another polymorphism studied here, rs1799817 located in exon 17 of the INSR gene, was associated with NAFLD risk; the "TT" genotype had a protective effect for NAFLD. The role of exon 17 in the function of INSR gene and insulin signal transduction is vital due to the fact that it encodes the tyrosine kinase domain of INSR protein ${ }^{(27)}$. Mutations in the tyrosine kinase domain (exon 17-21) of INSR gene cause severe hyperinsulinemia and insulin resistance ${ }^{(28)}$. Nevertheless, the molecular mechanism through which rs1799817 variant may influence the function of INSR gene is still speculative and unknown. Rs1799817 does not change the amino acid sequence of INSR protein (His1085His), although growing evidence indicates the likely effect of this type of SNPs in altering protein function ${ }^{(29)}$. The other possible way is the rs1799817 effect on INSR mRNA level through the control of mRNA splicing or mRNA stability. One hypothesis is that the rs1799817 "C" allele gives rise to a defect in the function of INSR protein and, in turn, impairs the biological response to insulin and leads to insulin resistance and finally NAFLD. This theory is biologically plausible and in accordance with it, the "T" allele of INSR rs1799817 polymorphism has a protective effect for $\mathrm{T} 2 \mathrm{D}^{(16)}$. More interestingly, recent evidence has also indicated that the "CC" genotype of rs1799817 significantly increases $\mathrm{IR}^{(14)}$. Additionally, the frequency of the " $T$ " allele was higher in the controls compared with the insulin-resistant subjects ${ }^{(30)}$ and the " $\mathrm{T}$ " allele was more frequent in subjects with normal glucose tolerance than cases with type 2 diabetics, emphasizing the protective effect of " $T$ " allele towards insulin resistance ${ }^{(31)}$. These findings are in concordance with the above hypothesis and our finding. The other possible hypothesis linking INSR rs1799817 variant with NAFLD risk is through linkage disequilibrium. Rs1799817 may not be a functional polymorphism. Instead it might be in complete or partial linkage disequilibrium with an unidentified functional polymorphism of INSR gene. In support of our hypothesis, it has also been demonstrated that the decrease of hepatic CEACAM1 a transmembrane glycoprotein that undergoes phosphorylation by the insulin receptor tyrosine kinase and promotes the clearance of insulin from the blood largely in liver - causes insulin resistance, hyperinsulinemia, and hepatosteatosis and its overexpression curtails these metabolic abnormalities associated with NAFLD ${ }^{(32)}$. And finally, gene polymorphisms that impair INSR signaling favor insulin resistance, obesity, and fibrosis development in NAFLD. The ectoenzyme nucleotide pyrophosphate phosphodiesterase 1 (ENPP1) which interacts directly with INSR inhibits insulin signaling and when overexpressed causes insulin resistance. The $121 \mathrm{Gln}$ allele of ENPP1 Lys121Gln polymorphism is a gainof-function allele causing stronger interaction with INSR and inhibition of its kinase activity ${ }^{(22,33)}$

The other gene studied here, INS, is also involved in maintaining glucose homeostasis. No significant association was detected between the INS rs3842752 variant - located in 3'UTR - and the INS rs689 polymorphism - located in promoter - and NAFLD susceptibility. Alterations in 3'UTR or promoter sequence may directly affect the function of protein. Alternatively, these variations per se might not be functional, instead they can be associated with epigenetic modifications that have functional effects on gene expression ${ }^{(34)}$. Previous studies have reported elevated insulin concentrations in NAFLD patients than controls $\mathrm{s}^{(10)}$ as well as significant associations between circulating insulin level and INS gene polymorphisms ${ }^{(11)}$. Notwithstanding the biological plausibility, INS may not be a predisposing gene for NAFLD. Of course, in order to conclude that the gene does not play a role in the development and progression of NAFLD, other INS gene polymorphisms should be examined in other studies.

The present case-control study was well designed and we conducted multicenter collaborative research. We also used liver biopsy as the gold standard method for confirming the diagnosis of NAFLD. However, when interpreting our results, some potential limitations should be considered. One limitation was the modest sample size that precluded doing detailed analyses. Another limitation was our lack of information on serum levels of insulin as well as HOMA-IR index. The other limitation was a potential information bias from the case-control study design. 


\section{CONCLUSION}

In summary, our findings reinforce the hypothesis that genetic polymorphisms related to insulin signaling pathway might play a role in NAFLD susceptibility. And interestingly, this observation is relevant from a theoretical viewpoint. Nonetheless, our results remain to be validated in additional investigations.

\section{ACKNOWLEDGEMENTS}

The authors thank all patients and healthy blood donors for providing blood samples.

\section{Authors' contribution}

Nobakht H: performing the experiments; analysis and interpretation of data; coordination responsibility; drafting of manuscript. Mahmoudi T: study conception and design; supervising the project; analysis and interpretation of data; drafting of manuscript. Sabzikarian M: acquisition of data; performing statistical analyses; drafting of manuscript. Tabaeian SP, Rezamand G, Asadi A, Farahani H, Dabiri R: acquisition of data; survey execution; drafting of manuscript. Mansour-Ghanaei F, Maleki I: acquisition of data; drafting of manuscript. Zali MR: acquisition of data; acquisition of the financial support; drafting of manuscript.

\section{Orcid}

Hossein Nobakht: 0000-0001-9386-2280.

Touraj Mahmoudi: 0000-0002-3220-6252.

Mohammad Sabzikarian: 0000-0001-7728-5444.

Seidamir Pasha Tabaeian: 0000-0001-5260-5667.

Gholamreza Rezamand: 0000-0002-4305-2420.

Asadollah Asadi: 0000-0003-3314-2948.

Hamid Farahani: 0000-0002-1262-1854.

Reza Dabiri: 0000-0003-4506-9901.

Fariborz Mansour-Ghanaei: 0000-0002-6264-0025.

Iradj Maleki: 0000-0003-2395-8118.

Mohammad Reza Zali: 0000-0002-9027-4560.

Nobakht H, Mahmoudi T, Sabzikarian M, Tabaeian SP, Rezamand G, Asadi A, Farahani H, Dabiri R, Mansour-Ghanaei F, Maleki I, Zali MR. Insulina e polimorfismos do gene do receptor de insulina e a suscetibilidade à doença hepática gordurosa não alcoólica. Arq Gastroenterol. 2020;57(2):203-8.

RESUMO - Contexto - A doença hepática gordurosa não alcoólica (NAFLD) é uma preocupação global crescente da saúde definida pelo excesso de teor de gordura hepática na ausência de consumo excessivo de álcool. Objetivo - Dado o papel crucial da resistência à insulina no NAFLD, criou-se a hipótese de que os polimorfismos genéticos da insulina (INS) e do receptor de insulina (INSR) podem estar associados ao risco de NAFLD. Métodos - Um total de 312 indivíduos, incluindo 153 casos com NAFLD comprovado por biópsia e 159 controles foram inscritos neste estudo de caso-controle. Quatro polimorfismos em genes INS (rs3842752, rs689) e INSR (rs1052371, rs1799817) foram genotipados utilizando o método PCRRFLP. Resultados - Os casos com NAFLD foram mais idosos e apresentaram maior IMC, pressão arterial sistólica, pressão arterial diastólica, bem como níveis séricos mais elevados de aspartato aminotransferase, de alanina aminotransferase e de gama glutamil transpeptidase do que os controles $(P<0,001)$. O genótipo "TT" de INSR rs1799817 em comparação com o genótipo "CC" ocorreu com mais frequência nos controles do que os casos com NAFLD e a diferença permaneceu significativa após ajuste para fatores de confusão $(P=0,018 ; \mathrm{OR}=0,10, \mathrm{IC} 95 \%=0,02-0,76)$. No entanto, não foi encontrada diferença significativa para INS rs3842752, INS rs689 e INSR rs1052371 polimorfismos genéticos entre os casos com NAFLD e os controles antes ou depois do ajuste para os fatores de confusão. Conclusão - Esses achados corroboram a hipótese de que os polimorfismos genéticos relacionados à resistência à insulina desempenham um papel na suscetibilidade do NAFLD. Especificamente, o genótipo INSR rs1799817 “TT" teve um efeito protetor para o NAFLD. No entanto, nossos resultados necessitam ser validados em outros estudos.

DESCRITORES - Hepatopatia gordurosa não alcoólica. Resistência à insulina. Receptor de insulina. Polimorfismo genético.

\section{REFERENCES}

1. Araújo AR, Rosso N, Bedogni G, Tiribelli C, Bellentani S. Global epidemiology of non-alcoholic fatty liver disease/non-alcoholic steatohepatitis: What we need in the future. Liver Int. 2018;38:47-51.

2. Haukeland JW, Konopski Z, Linnestad P, Azimy S, Marit Løberg E, Haaland $\mathrm{T}$, et al. Abnormal glucose tolerance is a predictor of steatohepatitis and fibrosis in patients with non-alcoholic fatty liver disease. Scand J Gastroenterol. 2005;40:1469-77.

3. Eguchi Y, Eguchi T, Mizuta T, Ide Y, Yasutake T, Iwakiri R, et al. Visceral fat accumulation and insulin resistance are important factors in nonalcoholic fatty liver disease. J Gastroenterol. 2006;41:462-9.

4. Brunt EM, Kleiner DE, Wilson LA, Unalp A, Behling CE, Lavine JE, et al. NASH Clinical Research Network A list of members of the Nonalcoholic Steatohepatitis Clinical Research Network can be found in the Appendix. Portal chronic inflammation in nonalcoholic fatty liver disease (NAFLD): a histologic marker of advanced NAFLD-Clinicopathologic correlations from the nonalcoholic steatohepatitis clinical research network. Hepatology. 2009;49:809-20.

5. Bellentani S, Scaglioni F, Marino M, Bedogni G. Epidemiology of non-alcoholic fatty liver disease. Dig Dis. 2010;28:155-61.

6. Dietrich P, and Hellerbrand. Non-alcoholic fatty liver disease, obesity and the metabolic syndrome. Best practice and research. Best Pract Res Clin Gastroenterol. 2014;28:637-53.
7. Ohmi S, Ono M, Takata H, Hirano S, Funakoshi S, Nishi Y, et al. Analysis of factors influencing glucose tolerance in Japanese patients with non-alcoholic fatty liver disease. Diabetol Metab Syndr. 2017;9:65.

8. Gholam PM, Flancbaum L, Machan JT, Charney DA, Kotler DP. Nonalcoholic fatty liver disease in severely obese subjects. Am J Gastroenterol. 2007;102:399408 .

9. Li M, Zhang S, Wu Y, Ye J, Cao X, Liu J, et al. Prevalence of insulin resistance in subjects with nonalcoholic fatty liver disease and its predictors in a Chinese population. Dig Dis Sci. 2015;60:2170-6.

10. Siddiqui MS, Fuchs M, Idowu MO, Luketic VA, Boyett S, Sargeant C, et al. Severity of nonalcoholic fatty liver disease and progression to cirrhosis associate with atherogenic lipoprotein profile. Clin Gastroenterol Hepatol. 2015;13:1000-8.

11. Le Stunff C, Fallin D, Schork NJ, Bougnères P. The insulin gene VNTR is associated with fasting insulin levels and development of juvenile obesity. Nat Genet. 2000;26:444-6.

12. Andraweera PH, Gatford KL, Dekker GA, Leemaqz S, Russell D, Thompson $\mathrm{SD}$, et al. Insulin family polymorphisms in pregnancies complicated by small for gestational age infants. Mol Hum Reprod. 2015;21:745-52.

13. Wang L, Mi J, Wu JX, Zhao XY, Cheng H, Ding XY, et al. Study on the relationship between polymorphism of insulin-receptor gene EXON2-2257 and insulin resistance in Chinese people. Zhonghua Liu Xing Bing Xue Za Zhi. 2004;25:49-53. 
14. Gangopadhyay S, Agrawal N, Batra A, Kabi BC, Gupta A. Single nucleotide polymorphism on exon 17 of insulin receptor gene influences insulin resistance in PCOS: a pilot study on North Indian women. Biochem Genet. 2016;54:158-68.

15. Chen ZJ, Shi YH, Zhao YR, Li Y, Tang R, Zhao LX, et al. Correlation between single nucleotide polymorphism of insulin receptor gene with polycystic ovary syndrome. Zhonghua Fu Chan Ke Za Zhi. 2004;39:582-5.

16. Bodhini D, Sandhiya M, Ghosh S, Majumder PP, Rao MR, Mohan V, et al. Association of His 1085 His INSR gene polymorphism with type 2 diabetes in South Indians. Diabetes Technol Ther. 2012;14:696-700.

17. Sokhi J, Sikka R, Raina P, Kaur R, Matharoo K, Arora P, et al. Association of genetic variants in INS (rs689), INSR (rs1799816) and PP1G.G (rs 1799999) with type 2 diabetes (T2D): a case-control study in three ethnic groups from NorthWest India. Mol Genet Genomics. 2016;291:205-16.

18. Brunt EM, Janney CG, Di Bisceglie AM, Neuschwander-Tetri BA, Bacon BR Nonalcoholic steatohepatitis: a proposal for grading and staging the histological lesions. Am J Gastroenterol. 1999;94:2467-74.

19. Salamone F, and Bugianesi E. Nonalcoholic fatty liver disease: the hepatic trigge of the metabolic syndrome. J Hepatol. 2010;53:1146-7.

20. Atay K, Canbakan B, Koroglu E, Hatemi I, Canbakan M, Kepil N, et al. Apoptosis and disease severity is associated with insulin resistance in non-alcoholic fatty liver disease. Acta Gastroenterol Belg. 2017;80:271-7.

21. Fujii H, Imajo K, Yoneda M, Nakahara T, Hyogo H, Takahashi H, et al. HOMA-IR: An independent predictor of advanced liver fibrosis in nondiabetic non-alcoholic fatty liver disease. J Gastroenterol Hepatol. 2019;34:1390-5.

22. Dongiovanni P, Valenti L, Rametta R, Daly AK, Nobili V, Mozzi E, et al. Genetic variants regulating insulin receptor signaling are associated with the severity of liver damage in patients with non-alcoholic fatty liver disease. Gut. 2010;59: 267-73.

23. Michael MD, Kulkarni RN, Postic C, Previs SF, Shulman GI, Magnuson MA, et al. Loss of insulin signaling in hepatocytes leads to severe insulin resistance and progressive hepatic dysfunction. Mol Cell. 2000;6:87-97.
24. Taylor SI, Kadowaki T, Kadowaki H, Accili D, Cama A, McKeon C. Mutations in insulin-receptor gene in insulin-resistant patients. Diabetes Care.1990;13:257-79.

25. Conne B, Stutz A, Vassalli JD. The 3' untranslated region of messenger RNA: a molecular "hotspot" for pathology? Nat Med. 2000;6:637-41.

26. Malodobra M, Pilecka A, Gworys B, Adamiec R. Single nucleotide polymorphisms within functional regions of genes implicated in insulin action and association with the insulin resistant phenotype. Mol Cell Biochem. 2011;349:187-93.

27. Seino S, Seino M, Bell GI. Human insulin receptor gene: partial sequence and amplification of exons by polymerase chain reaction. Diabetes. 1990;39:123-8.

28. Moller DE, Yokota A, White MF, Pazianos AG, Flier JS. A naturally occurring mutation of insulin receptor alanine 1134 impairs tyrosine kinase function and is associated with dominantly inherited insulin resistance. J Biol Chem. 1990;265:14979-85.

29. Kimchi-Sarfaty C, Oh JM, Kim IW, Sauna ZE, Calcagno AM, Ambudkar SV, et al. A silent polymorphism in the MDR1 gene changes substrate specificity. Science. 2007:315:525-8.

30. Skrgatić L, Baldani DP, Gersak K, Cerne JZ, Ferk P, Corić M. Genetic polymorphisms of INS, INSR and IRS-1 genes are not associated with polycystic ovary syndrome in Croatian women. Coll Antropol. 2013;37:141-6.

31. Siegel S, Futterweit W, Davies TF, Concepcion ES, Greenberg DA, Villanueva $\mathrm{R}$, et al. A C/T single nucleotide polymorphism at the tyrosine kinase domain of the insulin receptor gene is associated with polycystic ovary syndrome. Fertil Steril. 2002;78:1240-3.

32. Al-Share QY, DeAngelis AM, Lester SG, Bowman TA, Ramakrishnan SK, Abdallah SL, et al. Forced hepatic overexpression of CEACAM1 curtails diet-induced insulin resistance. Diabetes. 2015;64:2780-90.

33. Prudente S, and Trischitta V. The pleiotropic effect of the ENPP1 (PC-1) gene on insulin resistance, obesity, and type 2 diabetes. J Clin Endocrinol Metab. 2006;91:4767-8.

34. Kuroda A, Rauch TA, Todorov I, Ku HT, Al-Abdullah IH, Kandeel F, et al Insulin gene expression is regulated by DNA methylation. PloS One. 2009;4:e6953. 